\title{
Clinical Reasoning: A 45-year-old man with progressive insomnia and psychiatric and motor symptoms
}

José Eduardo E. Lima, MD, Teddy S. Youn, MD, Christopher Robinson, DO, MS, Emily J. Gilmore, MD, Matthew Schrag, MD, PhD, Sirisha Sanamandra, MD, and Carolina B. Maciel, MD, MSCR

Neurology ${ }^{\circledR}$ 2020;94:e1213-e1218. doi:10.1212/WNL.0000000000009098

\section{Section 1}

A 45-year-old right-handed hypertensive man presented with a 6-month history of worsening neuropsychiatric symptoms, abnormal movements, and weight loss. He was hallucinating, apathetic, and having severe insomnia (total sleep duration of 1-2 hours/night). During sleep, his wife noted labored and sonorous breathing. Six months before admission, he led a healthy and active lifestyle.

In the weeks preceding admission, the patient developed short-term memory loss, confabulation, and complete lack of insight to his symptoms. Weekly, he was working at least 40 hours as a public works employee plus 20 hours as a mechanic. He consumed nearly 4 cans/day of beer and had prior tobacco exposure (15 pack-years, quit 14 years prior to presentation). Family history was notable for Parkinson disease (PD).

On examination, pulse oximetry was $98.9 \%$, heart rate was 94 beats per minute, blood pressure was $161 / 89 \mathrm{~mm} \mathrm{Hg}$, and respiratory rate was 18 breaths per minute. Systemic examination revealed a thin, middle-aged man in no acute distress. Neurologic examination was notable for binocular diplopia (worst on midline and right gaze), postural tremor, whole body akathisia, multifocal and asynchronous myoclonic jerks, and choreiform movements of the legs while in a sitting position. An exaggerated startle response, progressive deficits in executive function and visuospatial skills, and involuntary chewing were also present (video 1).

\section{Question for consideration:}

1. What differential diagnoses and initial workup should you consider?
Correspondence Dr. Maciel

Carolina.Maciel@

neurology.ufl.edu

MORE ONLINE

- Videos

\section{GO TO SECTION 2}

From the Ribeirão Preto Medical School (J.E.E.L.), University of São Paulo, Brazil; Department of Neurology (T.S.Y., C.R., C.B.M.), UF Health Shands Hospital, University of Florida College of Medicine, Gainesville; Department of Neurology (E.J.G., S.S., C.B.M.), Yale University School of Medicine, New Haven, CT; and Department of Neurology (M.S.), Vanderbilt University Medical Center, Nashville, TN.

Go to Neurology.org/N for full disclosures. Funding information and disclosures deemed relevant by the authors, if any, are provided at the end of the article. 


\section{Section 2}

The symptoms and signs in this vignette point to a process likely involving the bilateral frontotemporal lobes and the basal ganglia. In cases of diffuse cortical and subcortical dysfunction, infections such as syphilis, neuroborreliosis, and HIV should be considered.

Progressive clinical worsening may suggest a degenerative process such as frontotemporal dementia or prion diseases. PD, Alzheimer disease, and Lewy body disorders are less likely at this age and also less likely to exhibit a rapid progression. Although less common, autoimmune encephalitis, hereditary and acquired leukoencephalopathies, paraneoplastic syndromes, and vitamin deficiencies are also possible. Acute toxicity and substance-induced disorders should be ruled out. In this setting, empiric treatment for Wernicke and Korsakoff encephalopathy is appropriate.

A complete blood count and comprehensive metabolic panel including liver profile were significant for a sodium level of $122 \mathrm{mEq} / \mathrm{L}$. Tests for reversible causes of dementia including thyroid function tests, vitamin $\mathrm{B}_{1}$ and $\mathrm{B}_{12}$ levels, HIV and syphilis screening, ammonia, and urine toxicologic screen were negative.

The likely culprit of the patient's hyponatremia was syndrome of inappropriate antidiuretic hormone secretion, as he was euvolemic, with normal urine osmolality, and had urine sodium $>20 \mathrm{mEq} / \mathrm{L}$. Brain MRI without gadolinium revealed no parenchymal abnormalities, normal ventricular size and configuration, and no restricted diffusion. FDG-PET revealed asymmetric hypometabolism in the left thalamus. EEG was normal except for rudimentary sleep structures, which can be found in healthy patients but may also indicate thalamocortical dysfunction.

CSF analysis showed normal levels of protein and glucose, an erythrocyte count of 21 , and no pleocytosis. The immunoglobulin G index was elevated at $696 \mathrm{mg} / \mathrm{L}$. Fungal and bacterial cultures were negative, as were serologies for cytomegalovirus, varicella-zoster virus, Epstein-Barr virus, herpes simplex virus, and Lyme disease. Protein analysis of A 342 / total tau index and phosphorylated tau were 0.46 and 18.75 , respectively, with the former consistent with Alzheimer disease, but the latter not. Analysis of 14-3-3 was indeterminate and tau protein was negative.

\section{Question for consideration:}

1. What would you include in the workup for autoimmune etiologies?

Rheumatoid factor, anti-Ro, anti-La, anti-neutrophil cytoplasmic antibody, complement testing ( $\mathrm{C} 3$ and $\mathrm{C} 4)$, antidouble-stranded DNA, antinuclear antibody, and thyroperoxidase antibody were negative. Both CSF and serum paraneoplastic antibody screening were performed. However, low levels $(240 \mathrm{pmol} / \mathrm{L})$ of anti-voltage-gated potassium channel antibodies (anti-VGKC-Ab) were detected in the serum. LGI1 and CASPR subtypes were negative. Subsequent CT of the chest, abdomen, and pelvis did not reveal an underlying malignancy.

\section{Questions for consideration:}

1. Would you treat this patient empirically?

2. What therapeutic approaches could be used?

\section{GO TO SECTION 3}




\section{Section 3}

In the setting of serum anti-VGKC, hyponatremia, and neuropsychiatric syndrome, autoimmune neuromyotonia (Morvan syndrome) with superimposed limbic encephalitis was considered. Thus, initial treatment included pulse dose methylprednisolone and IV immunoglobulin.

Clinical deterioration ensued with decreased verbal output, increasing agitation, and profound dysautonomia (diaphoresis, pallor alternating with facial flushing, tachycardia, and wide body temperature fluctuations). Four weeks after therapy initiation, plasmapheresis was employed without response. The patient developed profound central hypoventilation, requiring mechanical ventilation, ultimately requiring tracheostomy and gastrostomy tube placement.

\section{Question for consideration:}

1. What are additional rescue immunotherapies?

GO TO SECTION 4 


\section{Section 4}

Given the lack of response to initial immunotherapy, treatment should be individualized. Despite the absence of prospective and randomized trials, rituximab and cyclophosphamide can be considered in autoimmune encephalitis. ${ }^{1}$ A complete course of rituximab followed, without clinical improvement despite appropriate depletion of B-cell lines on flow cytometry (video 2 ).

During the subsequent 5 weeks, worsened hypercapneic respiratory failure requiring mechanical ventilation and sepsis ensued. Repeat MRI showed global cerebral atrophy (figure e-1, doi.org/10.5061/dryad.2hm3d5g).

\section{Question for consideration:}

1. Would you reconsider your differential diagnosis?

Therapeutic responses are highly variable in autoimmune encephalitis; lack of improvement following initial and alternative immunotherapies is not uncommon. ${ }^{2}$ Therefore, poor therapeutic responses do not necessarily mean incorrect diagnoses. In our case, genetic testing for prion diseases had been requested upon admission, but still had pending results.

After a progressive 6-month course refractory to interventions, the patient was transitioned to comfort measures according to his family's wishes. An autopsy was performed.

Immunohistochemical studies showed weak immunoreactivity of the prion protein $(\mathrm{PrP})$ in granular deposits restricted to neurons in the thalamus. There was minimal spongiform degeneration in the entorhinal cortex and striatum. Western blot confirmed the presence of scrapie protease $\mathrm{K}$ resistant protein $\left(\mathrm{PrP}^{\mathrm{sc}}\right)$ and genetic testing detected a D 178N/129M mutation in the prion protein gene $(P R N P)$, confirming the diagnosis of fatal familial insomnia (FFI). Neurohistopathology is displayed in figure e-2 (doi.org/10.5061/ dryad. $2 \mathrm{hm} 3 \mathrm{~d} 5 \mathrm{~g}$ ).

FFI is a rare autosomal dominant prion disease that frequently presents in the fourth or fifth decades, with disease length influenced by PRNP polymorphism. ${ }^{3}$ Symptoms are related to the buildup of $\operatorname{PrP}^{\mathrm{sc}}$ originated from the conversion of the normal prion protein $\left(\mathrm{PrP}^{\mathrm{C}}\right)$. A PRNP gene point mutation, mainly D178N/129M, which replaces aspartic acid with asparagine, and the presence of a methionine codon at position 129 are associated with the disease.

Typically, FFI begins with attention impairment, insomnia, and progressive dementia. This may be followed by endocrine abnormalities, movement disorders, and autonomic dysfunction. Gait ataxia, oral dysphagia, central apnea, and weight loss may ensue. Most of these symptoms were present in this case.

Psychiatric symptoms, including depression and psychotic disturbances, are uncommon but may suggest FFI if associated with the described symptoms. If atypical manifestations of a genetic disease occur, 2 or more separate diseases can be considered.

\section{Question for consideration:}

1. What are the implications of this diagnosis to his family?

GO TO SECTION 5 


\section{Section 5}

Proper genetic counseling prior to testing is paramount when a genetic disease is suspected. In FFI, genetic testing may have implications in life and family planning given its autosomal dominance with high penetrance. Upfront discussions with family and surrogates (if minor or incapacitated individuals) are essential. In these cases, surrogates should consider deferring genetic testing until adulthood, as FFI is an adult-onset condition with no therapeutic options (figure).

\section{Question for consideration:}

1. How would you explain the negative results of the patients' children?

\section{Discussion}

The majority of prion diseases have no identifiable cause and are associated with sporadic forms. Approximately 10\%-15\% of patients have genetic forms, including FFI. In cases of heterozygosis, the mutation may not be transmitted to future generations. Of note, few cases without a clear family history of FFI have been reported, ${ }^{4,5}$ possibly related to de novo mutations or spontaneous PrP changes.

When compared to other prion diseases, FFI is associated with a longer interval between onset and diagnosis. ${ }^{6}$ The spectrum of differential diagnoses and current diagnostic tools with poor sensitivity challenges early diagnosis. In our case, the clinical presentation in the setting of positive serum antiVGKC resembling Morvan syndrome, limbic encephalitis, and Isaacs syndrome could have delayed the final diagnosis. The relevance of anti-VGKC positivity alone in the diagnostic workup remains debatable. ${ }^{7}$
In FFI, CT and MRI reveal nonspecific findings but are important to rule out other causes of rapidly progressive dementia. ${ }^{8,9}$ FDG-PET scans can be used prior to the development of clinical symptoms, displaying areas of hypometabolism within the thalamus and cingulate cortex. ${ }^{9}$

EEG and 14-3-3 protein analysis are not helpful in diagnosing FFI. ${ }^{10}$ Histopathology, immunohistochemistry, and Western blotting have all been used for isolation of $\operatorname{PrP}^{\text {sc }}$ within the thalamus. ${ }^{8}$ Gene sequencing of the PRNP gene confirms the diagnosis.

The management of FFI consists of supportive care. For agitation, benzodiazepines, neuroleptics, and antidepressants may have transient benefits. Once symptoms begin, prognosis is poor, with a median survival of 18 months. ${ }^{4}$ When clinically suspected, early genetic screening may avoid unnecessary interventions.

This case illustrates the importance of considering FFI and other prion diseases in cases of rapidly progressive dementia, sleep impairment, and motor and psychiatric symptoms.

\section{Acknowledgment}

The authors thank the patient's family for their collaboration and feedback on the content of this article.

\section{Study funding}

No targeted funding reported.

\section{Disclosure}

The authors report no disclosures relevant to the manuscript. Go to Neurology.org/N for full disclosures.

Figure Family genetic pedigree

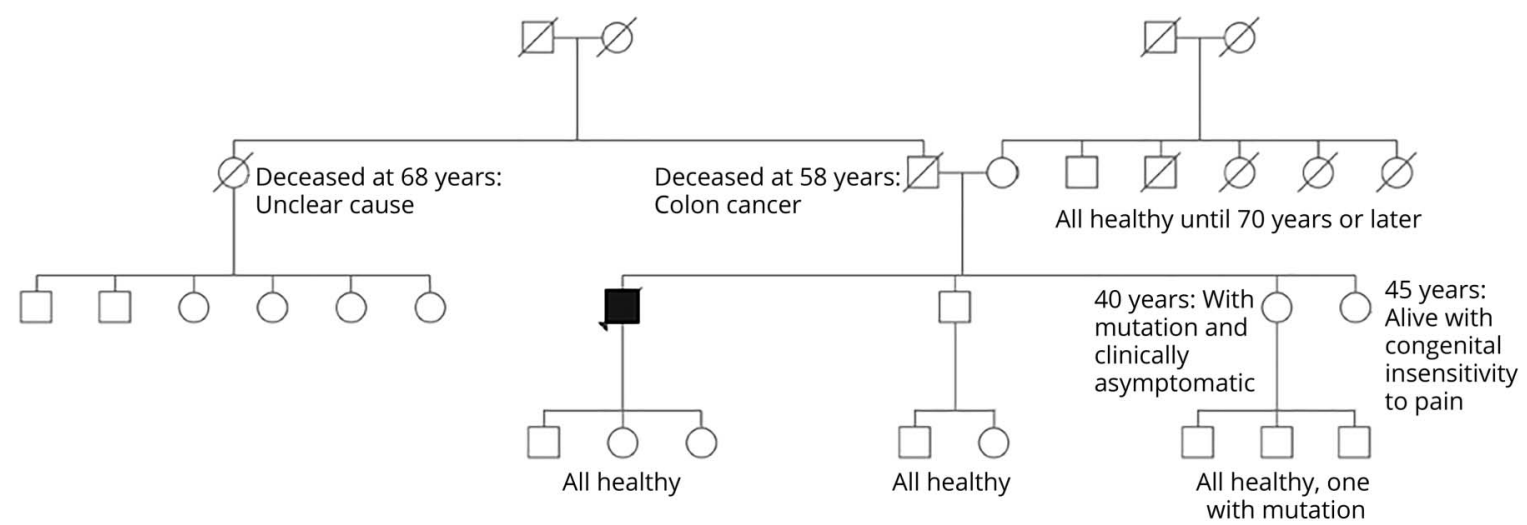

This Polish American family had no history of presenile neurodegenerative disorders in the maternal lineage, but evaluation of the paternal lineage was complicated by early mortality in the proband's father from cancer and estrangement from the remaining family. There was no known consanguinity. Of the proband's 3 full siblings, a brother declined genetic screening and his children were not tested. One sister (coincidentally severely disabled due to profound congenital insensitivity to pain) tested negative and another clinically normal sister in her 40s was found to share the mutation observed in the proband. The proband's children underwent screening: none have the fatal familial insomnia (FFI) mutation. Regarding the sister who shares the mutation, 2 of her children were tested: the youngest child has the mutation and is asymptomatic; the oldest child tested negative. 


\section{Appendix Authors}

\begin{tabular}{|c|c|c|c|}
\hline Name & Location & Role & Contribution \\
\hline $\begin{array}{l}\text { José Eduardo } \\
\text { E. Lima }\end{array}$ & $\begin{array}{l}\text { Ribeirão Preto } \\
\text { Medical School, } \\
\text { University of São } \\
\text { Paulo }\end{array}$ & Author & $\begin{array}{l}\text { Analyzed the data, } \\
\text { drafted the } \\
\text { manuscript for } \\
\text { intellectual content }\end{array}$ \\
\hline $\begin{array}{l}\text { Teddy S. } \\
\text { Youn, MD }\end{array}$ & $\begin{array}{l}\text { University of Florida } \\
\text { College of Medicine }\end{array}$ & Author & $\begin{array}{l}\text { Data collection, } \\
\text { revision for } \\
\text { intellectual content }\end{array}$ \\
\hline $\begin{array}{l}\text { Christopher } \\
\text { Robinson, } \\
\text { DO, MS }\end{array}$ & $\begin{array}{l}\text { University of Florida } \\
\text { College of Medicine }\end{array}$ & Author & $\begin{array}{l}\text { Drafting and } \\
\text { revision for } \\
\text { intellectual content }\end{array}$ \\
\hline $\begin{array}{l}\text { Emily J. } \\
\text { Gilmore, MD }\end{array}$ & $\begin{array}{l}\text { Yale University School } \\
\text { of Medicine }\end{array}$ & Author & $\begin{array}{l}\text { Data collection, } \\
\text { revision for } \\
\text { intellectual content }\end{array}$ \\
\hline $\begin{array}{l}\text { Matthew } \\
\text { Schrag, MD }\end{array}$ & $\begin{array}{l}\text { Vanderbilt University } \\
\text { Medical Center }\end{array}$ & Author & $\begin{array}{l}\text { Data collection, } \\
\text { revision for } \\
\text { intellectual content }\end{array}$ \\
\hline $\begin{array}{l}\text { Sirisha } \\
\text { Sanamandra, } \\
\text { MD }\end{array}$ & $\begin{array}{l}\text { Yale University School } \\
\text { of Medicine }\end{array}$ & Author & Data collection \\
\hline $\begin{array}{l}\text { Carolina B. } \\
\text { Maciel, MD, } \\
\text { MSCR }\end{array}$ & $\begin{array}{l}\text { University of Florida } \\
\text { College of Medicine, } \\
\text { Yale University School } \\
\text { of Medicine }\end{array}$ & Author & $\begin{array}{l}\text { Data collection, } \\
\text { drafting and } \\
\text { revision for } \\
\text { intellectual content }\end{array}$ \\
\hline
\end{tabular}

\section{References}

1. Shin YW, Lee ST, Park KI, et al. Treatment strategies for autoimmune encephalitis. Ther Adv Neurol Disord 2018;11:1-19.

2. Lee WJ, Lee ST, Byun JI, et al. Rituximab treatment for autoimmune limbic encephalitis in an institutional cohort. Neurology 2016;86:1683-1691.

3. Montagna P, Cortelli P, Avoni P, et al. Clinical features of fatal familial insomnia: phenotypic variability in relation to a polymorphism at codon 129 of the prion protein gene. Brain Pathol 1998;8:515-520.

4. Montagna P, Gambetti P, Cortelli P, Lugaresi E. Familial and sporadic fatal insomnia. Lancet Neurol 2003;2:167-176.

5. Moody KM, Schonberger LB, Maddox RA, Zou WQ, Cracco L, Cali I. Sporadic fatal insomnia in a young woman: a diagnostic challenge: case report. BMC Neurol 2011; $11: 136$

6. Shi Q, Zhou W, Chen C, et al. The features of genetic prion diseases based on Chinese surveillance program. PLoS One 2015; 10:e139552.

7. van Sonderen A, Schreurs MW, de Bruijn MA, et al. The relevance of VGKC positivity in the absence of LGI1 and Caspr2 antibodies. Neurology 2016;86:1692-1699.

8. Shi XH, Han J, Zhang J, et al. Clinical, histopathological and genetic studies in a family with fatal familial insomnia. Infect Genet Evol 2010;10:292-297.

9. Cortelli P, Perani D, Montagna P, et al. Pre-symptomatic diagnosis in fatal familial insomnia: serial neurophysiological and 18FDG-PET studies. Brain 2006;129: 668-675.

10. Kovacs GG, Puopolo M, Ladogana A, et al. Genetic prion disease: the EUROCJD experience. Hum Genet 2005;118:166-174. 


\section{Neurology}

\section{Clinical Reasoning: A 45-year-old man with progressive insomnia and psychiatric and motor symptoms}

José Eduardo E. Lima, Teddy S. Youn, Christopher Robinson, et al.

Neurology 2020;94;e1213-e1218 Published Online before print February 27, 2020

DOI 10.1212/WNL.0000000000009098

This information is current as of February 27, 2020

\section{Updated Information \& Services}

References

Citations

Subspecialty Collections

Errata

Permissions \& Licensing

Reprints including high resolution figures, can be found at: http://n.neurology.org/content/94/11/e1213.full

This article cites 10 articles, 0 of which you can access for free at: http://n.neurology.org/content/94/11/e1213.full\#ref-list-1

This article has been cited by 1 HighWire-hosted articles: http://n.neurology.org/content/94/11/e1213.full\#\#otherarticles

This article, along with others on similar topics, appears in the following collection(s):

All Clinical Neurology

http://n.neurology.org/cgi/collection/all_clinical_neurology

All Genetics

http://n.neurology.org/cgi/collection/all_genetics

Prion disease; see Infections/prion

http://n.neurology.org/cgi/collection/prion_disease

Psychosis

http://n.neurology.org/cgi/collection/psychosis

An erratum has been published regarding this article. Please see next page or:

/content/95/7/325.3.full.pdf

Information about reproducing this article in parts (figures,tables) or in its entirety can be found online at:

http://www.neurology.org/about/about_the_journal\#permissions

Information about ordering reprints can be found online:

http://n.neurology.org/subscribers/advertise

Neurology ${ }^{\circledR}$ is the official journal of the American Academy of Neurology. Published continuously since 1951, it is now a weekly with 48 issues per year. Copyright @ 2020 American Academy of Neurology. All rights reserved. Print ISSN: 0028-3878. Online ISSN: 1526-632X.

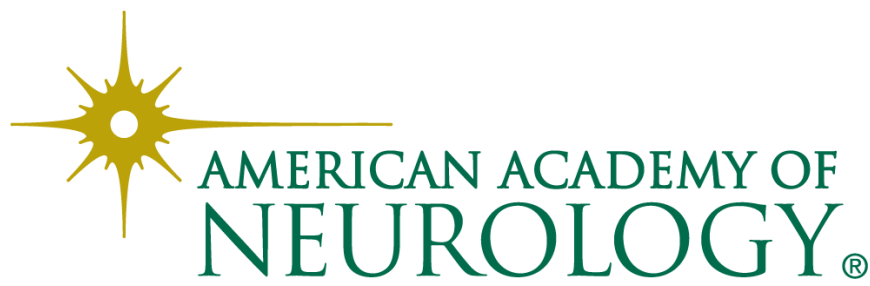




\section{Mortality among patients with idiopathic intracranial hypertension enrolled in the IH Registry}

Neurology ${ }^{\circledR}$ 2020;95:325. doi:10.1212/WNL.0000000000010352

In the final published version of the article "Mortality among patients with idiopathic intracranial hypertension enrolled in the IH Registry" (previously available as a post-acceptance publication ahead of print) by Hermes et al., the addendum "These findings should be interpreted with caution as the IHR database is likely subject to selection bias" was included as the last sentence in the Conclusions section of the Abstract, to clarify the interpretation of the conclusions noted, and to ensure the Abstract accurately reflects the authors' conclusions as they are stated in the Discussion section of the article itself. The editors regret the omission of this sentence from the previous version of the article.

\section{Reference}

1. Hermes SM, Miller NR, Waslo CS, et al. Mortality among patients with idiopathic intracranial hypertension enrolled in the IH Registry. Neurology 2020;95:e921-e929.

\section{Teaching NeuroImages: CNS pituitary-hypothalamic Langerhans cell histiocytosis in an adult}

Neurology ${ }^{\circledR}$ 2020;95:325. doi:10.1212/WNL.0000000000010320

In the Teaching NeuroImages article "Teaching NeuroImages: CNS pituitary-hypothalamic Langerhans cell histiocytosis in an adult" by Yeaney et al., ${ }^{1}$ published online January 13, 2020, and in print January 28, 2020, the reference to figure 1 should appear following this sentence: "MRI showed a $1.7-\mathrm{cm}$ enhancing mass involving the infundibulum and hypothalamus." The authors regret the error.

\section{Reference}

1. Yeaney GA, Kshettry VR, Isada C. Teaching NeuroImages: CNS pituitary-hypothalamic Langerhans cell histiocytosis in an adult. Neurology 2020;94:e434-e435.

\section{Clinical Reasoning: A 45-year-old man with progressive insomnia and psychiatric and motor symptoms \\ Neurology ${ }^{\circledR}$ 2020;95:325. doi:10.1212/WNL.0000000000010179}

In the Resident \& Fellow paper "Clinical Reasoning: A 45-year-old man with progressive insomnia and psychiatric and motor symptoms" by Lima et al., there is an error in the fifth paragraph of section 2 of the paper-the second sentence in this paragraph should read "The immunoglobulin $\mathrm{G}$ index was not elevated $(0.5)$ and no oligoclonal bands were observed in the CSF or serum." The authors regret the error.

\section{Reference}

1. Lima J, Youn T, Robinson C, et al. Clinical Reasoning: A 45-year-old man with progressive insomnia and psychiatric and motor symptoms. Neurology 2020;94:e1213-e1218. 